Ismail Musabegović ${ }^{1}$

UNION University, Belgrade Banking Academy

Mustafa Ozer ${ }^{2}$

Anadolu Üniversitesi

Milena Lazić ${ }^{3}$

Institute of Economic Sciences, Belgrade

Stefan Jovanović ${ }^{4}$

UNION University, Belgrade Banking Academy
ORIGINAL SCIENTIFIC ARTICLE

DOI: 10.5937/ekonomika2103075M

Received: April, 21. 2021.

Accepted: Jun, 18. 2021.

\title{
INTERPLAY BETWEEN DIGITAL TECHNOLOGIES AND BUSINESS PERFORMANCE IN BANKING INDUSTRY: GLOBAL AND REGIONAL PERSPECTIVES
}

\begin{abstract}
In order to remain competitive on both domestic and global market as well as to satisfy evolving consumers' needs, modern banks must not ignore the potential of digital and smart technologies. Taking into consideration the importance of digitalization as a new standard in business practice, the aim of this paper is to evaluate the impact of digitalization on the performance of banking sector globally and in SEE region. The main purpose of this paper is to test if the investments in information and communication technologies (ICT) contribute to the growth of profitability of banking sector as well as to the reduction of OPEX. In order to test the influence of investments in ICT on banking performance adequately, the static panel data models of fixed effects models were used. The results indicate that the influence of investments in ICT on OPEX defers on global and regional level. The results also indicate statistically significant positive relationship between investments in ICT and banks' profitability in SEE region.
\end{abstract}

Key words: digital technologies, smart technologies, investments in ICT, OPEX, profitability, banking industry

JEL classification: $C 1$, F3, G2

\section{МЕБУСОБНА ПОВЕЗАНОСТ ИЗМЕБУ ДИГИТАЛНИХ ТЕХНОЛОГИЈА И ПОСЛОВНИХ ПЕРФОРМАНСИ У БАНКАРСКОЈ ИНДУСТРИЈИ: ГЛОБАЛНА И РЕГИОНАЛНА ПЕРСПЕКТИВА}

\section{Апстракт}

Како би остале конкурентне на домаћем и глобалном тржишту, и како би задоволиле потребе потрочача чије се потребе континуирано менају,

\footnotetext{
${ }^{1}$ ismail.musabegovic@bba.edu.rs, ORCID ID 0000-0001-8137-8918

${ }^{2}$ muozer@gmail.com, ORCID ID 0000-0001-9852-8441

${ }^{3}$ milena.lazic@ien.bg.ac.rs, ORCID ID 0000-0002-8726-3422

${ }^{4}$ steffy_jov@hotmail.com, ORCID ID 0000-0003-2797-3016
} 
савремене банке не смеју да игноришу потениијал дигиталних и паметних технологија. Полазећи од значаја дигитализачије као новог стандарда у пословној пракси савремених организаиија, предмет овог рада представль оцена утииаја дигитализације на пословне резултате банкарског сектора глобално и урегиону ЈИЕ. Рад имаза иил да оцени да ли улагаға у инбормаиионокомуникационе технологије (ИКТ) доприносе расту профитабилности банкарског сектора, односно сманену ОПЕХ. У иилу адекватног тестирағь утицаја улагана у ИКТ на банкарске пербормансе, коришћени су статички ФЕ модели панел анализе. Резултати указују да се утииај инвестииија у ИКТ на ОПЕХ разликује на глобалном и регионалном нивоу. Резултати такође упућују на присуство статистички значајне позитивне везе између инвестиција у ИКТ и пробитабилности банака у региону ЈИЕ.

Клучне речи: дигиталне технологије, паметне технологије, улагаға у ИКТ, ОПЕХ, профитабилност, банкарска индустрија

\section{Introduction}

The traditional financial services industry is confronted with tremendous challenges, which result in substantial structural developments. In order to remain competitive on both domestic and global market, it is of great importance for financial institutions to concentrate on and understand the factors that drive these developments (Gerlach, 2020).

The importance of banks as financial intermediaries for the functioning of the contemporary economic systems is essential (Lončar et al., 2016). Banking environment has changed significantly in the last decade, redefining the main attributes of competition in traditional business models. In order to adequately understand the course of action banks should follow in the future, challenges which banking industry is currently confronted with must be observed first. All changes can be observed on two levels - the macro and the micro level.

Macro (external) environment. In macro environment, it is widely accepted that banks hold a unique intermediary role in sustainable development, but also have a difficult position after the 2008 financial crisis (Yip \& Bocken, 2018). Therefore, in the aftermath of the Global Crisis, conventional monetary policy has been constrained by low interest rates in many major economies (Lilley \& Rogoff, 2020). The era of low or even negative interest rates (on both European and US market) has changed the banking environment tremendously. Lowering the key rates by major central banks in order to recover the economy after the global financial crisis, expectedly transmitted to banks' offering rates imposing pressure on their earning ability. Thus banks were forced to change their operating models in order to find new ways to survive in circumstances banking sector has never been before. Since then, changes in banking industry worldwide seem only to be increasing.

Diminished interest rates firstly affected smaller banks which, following their size and no proportionally diminished OPEX, were acquired by the larger ones. In the era of low interest rates and no proportionally changed OPEX economy of scale seems to be an 
important factor to improve the overall competitiveness. In order to obtain larger number of clients (both corporate and retail), some banks dumped their selling prices (i.e. offering rates) even further. The other strategy that has been widely used refers to rising efficiency in providing services. Practically the "rat race" among the banks during the last decade has substantially changed their traditional role - in order to compete successfully on the global level in the era of thin profit margins and more restrictive regulative environment, banks regard technology and innovation as a top priority.

However, by digitalizing their operations banks become more efficient and more competitive. Digitalization also enable banks to reduce OPEX size by reducing the number of employees which are replaced by software solutions. In traditional banks, approximately $40 \%$ of OPEX belongs to employees' salaries. On the other hand, by digitalizing their operations banks also respond to changing consumer' behavior as well as evolving customers' needs (the so called "new digital generations"). In new digitalized environment products and services are more tailored-made in order to reflect distinctions in customers' needs and behavior. Banks are increasingly adopting and leveraging advanced technologies to deliver innovative financial products and services, such as artificial intelligence, advanced data analytics, machine learning, cloud computing, distributed ledger technology and application programming interfaces. With ICT now affecting every aspect of financial services, as well as with the presence of customercentric approach in all the major business models, digital platforms became an essential mechanism for engaging with existing and potential customers.

Micro (internal) environment. Consumer behavior and expectations are evolving, forcing not just banks, but the financial services industry to redefine their priorities (Hinton, 2020). In general, digitalization is highly derived by new generation i.e. digital civilization where consumers' expectations are oriented towards digital channels, so banks cannot afford to ignore it. If banks decide not to follow the path of digitalization they would easily lose the market shares by Fin-Tech companies which are increasingly present (firstly in the payment processing but also other segments of banking activities). Younger generations are in high demands for the banking sector to be up to date with the new digital solutions. Their expectations are based on features such as real-time reports, online, fast, paperless and customized loans, analytics of a customer's financial standing, investment decisions and other real-time actions. Accordingly, it is highly recommended that banks constantly monitor and evaluate the behavior of the Millennials (generation of young professionals which is important for banks both in terms of size and of high demand for banking services) in order to successfully satisfy their needs and expectations. Furthermore, it is also important to already start evaluating the behavior of the so-called "Z generation" - the youngest customers whose demand for banking services is expected to rocket in the following years.

Along with the changing preferences of new generations and their increasing usage of financial technologies, another challenge that has recently been observed in micro banking environment coincide with the raising popularity of FinTech companies. Based on the EY FinTech Adoption Index, the percentage of FinTech users increased significantly from $16 \%$ in 2015 to $64 \%$ in 2019, with the current awareness of FinTech on very high level (Ernst \& Young, 2019). These developments emphasize the importance of identifying potential drivers of FinTech adoption. According to EY Survey (Ernst \& Young, 2020) FinTech (and BigTech) companies benefit from the absence of legacy systems, which 
allow them to invest in the latest technology and customer experiences, rather than just keep existing systems ticking over. Accordingly, traditional banks are facing a dilemma on how to address FinTech as new competitors - co-operative or competitive (Gomber et al., 2017). Valverde and Fernandez (2020) consider that competition between traditional banks and tech companies is mostly driven by their relative ability to manage information sharing. Authors came to conclusion that regulation is still considering ways of providing a level playing field while industry participants are reacting with a mixture of strategies, many of them based mostly on cooperation.

Taking into account the main challenges that banking industry is currently facing as well as the importance of digitalization as a new standard in business practice, the subject of this paper is to evaluate the impact of digitalization on the performance of banking sector globally and in SEE region. The main purpose of this paper is to test if the investments in ICT contributes to the growth of profitability of banking sector as well as to the reduction of OPEX. The main contributions of this study primarily refer to the comparison of regional and global performance and the implications to the management of respective regional banks. The authors believe that there is significantly positive correlation between investments in ICT and the quality of banking services and products. In order to adequately test the influence of investments in ICT on banking performance, the static panel data models of fixed effects models were used. The rest of the paper is organized as follows. After the introductory remarks, the second part provides a brief overview of relevant literature in the field. The third, fourth and fifth parts refer to data used, methodology and empirical results. The conclusion is given in the last, sixth part.

\section{Literature review}

Digital transformation is becoming standard feature in an increasingly digital world, which has contributed to significant changes in business processes all over the world (Rodrigues et al., 2020). Industry 4.0 or Digital Revolution has changed the way we live by changing interactions with clients and companies, with business models and financial services as no exception (Mekinjić, 2019). Changes that business environment is constantly confronted with call for their identification, monitoring and a constant adapting of operations to new conditions. An adequate response of the companies requires them to evaluate and make proper use of the possible chances and avoid or minimize potential threats (Swacha-Lech, 2017). Kim et al. (2016) focus their research on the use of new technologies that enable the development of innovative, disruptive and differentiated financial services or products. Philippon (2016) believes that these services and products have the potential to disrupt existing industry structures and set new boundaries.

Today's key challenge for firm growth relies in the integration of digital technologies and their use in new business models (Bouncken, 2020). Whilst the banking industry is well-known for being conservative, when it comes to change and the implementation of new technologies, it is time for the commercial banks to increase their speed of innovation, focusing on out-of-the-box thinking in constantly changing environment (Hinton, 2020). Some authors (Mekinjić, 2019) consider the digitalization of banking process to be in its full capacity, taking into account that this process also includes other component parts of the Industry 4.0, such as blockchain networks, artificial 
intelligence, IoT, biometrics, cooperation of banks with FinTech companies, preparation of the platform and other services for the Generation Z. Banks and other financial organizations are going toward transition and establishing structures that accommodate the use of digitalized customer services and operations, in order to increase the level of organizational performance (Kioko, 2014). In their paper group of authors (Nadella et al., 2017) emphasized that according to Cap Gemini about $87 \%$ of companies consider implementation of new technologies to be the major competitive advantage, highlighting that "going digital" is a top priority for everyone and for banks especially. Nevertheless, it is believed that the optimal level of digitalization ultimately depends on customer base.

Digital banking has modified banking industry considerably, rising its efficiency and productivity while in the same time delivering ultimate customer satisfaction. Digital transformation allows banks to provide superior services which result in better customers' experience (Belk, 2013; Hoffman et al., 2013; Sheth \& Solomon, 2014; Gunter, 2016; Rodrigues et al., 2020). Banks and other financial institutions thus pay attention to the development, acquisition, and incorporation of related technologies to profit from these developments. (Nylund et al., 2018). Furthermore, accelerated digitalization has made banks intensively re-examine traditional business models in order to respond quickly and efficiently to the new demands of their clients while offering safe and userfriendly services (Mekinjić, 2019). According to Price Waterhouse Cooper's report (Price Waterhouse Cooper, 2011) digital banking is ready and set to overtake branch banking practices and networks as a preferred channel by customers, both corporate and individual. Hinson and Sorensen (2006) find that benefits of this practice are visible in terms of speed, accessibility, trackability, serving wider market segments, connecting specific market audiences, no content restrictions, worldwide circulation, efficient use of technology, modern touch and 24/7 availability.

Changes which have been taking place require banks to take bold action to transform, to make the most of evolving technologies, stay ahead of new competitors and meet customer demands (Ernst \& Yung, 2020). Effective implementation of ICT contributes to faster exchange of data and information which has positive implications to companies' performance (Ready \& Zimmerman, 2000). ICT offers tremendous potential and variety of opportunities for the banking industry. On the first hand, it provides a costeffective, rapid and systematic provision of services to the customer. On the other hand, ICT saves the time of the customers and employees, cuts down the OPEX and facilitates the network transactions. However, some authors (Serebrennikova et al., 2019) find competitiveness and sustainable development of modern banks to be mainly dependent on innovation and implementation of new technologies. Sustainable competitiveness encourages nations not only to meet the needs of the current generation but also to sustain or even expand national wealth in the future without depleting natural and social capital (Delgosha et al., 2020). Delgosha et al. conducted research on panel data from 127 countries which led them to conclusion that advancing companies' perception of how to access ICT infrastructures and capabilities, combined with the adoption and usage of ICT could result in different degrees of sustainable competitiveness which is of substantial importance to the overall economic growth and prosperity.

Pousttchi et al. (2015) considered the topic of digital transformation in retail banking. Consequently, focusing on ICT, digitalization of business processes, models and networks lead to the new opportunities for profit growth. It is clear that the fast 
development of the Internet as well as the usage of new possibilities which the digital technologies have brought about, have made significant changes in all the areas of business (Prokopović et al., 2016).

In the end, security and trust are still key determinants of banking business (Mekinjić, 2019). An efficient use of the opportunities offered by digitalization process allows banks not only to tailor their services to customer expectations, streamline processes and reduce costs, but also to increase transactional security by reducing money laundering and terrorist financing (Swacha-Lech, 2017). While the ICT mostly presents opportunities, it may also pose new sources of risks. Relying on innovative technologies requires effective IT support as well as the implementation of other risk management processes. Besides that, ICT can be developed in-house or outsourced depending on internal strategy.

Liberalization of the financial market of the SEE region has been carried out in the last 20 years and was followed by the adaptation to standards and regulation of the European Union. Accordingly, authors believe that the existing gap between performance of the global and regional banks is narrowing which implies that the end-users benefit by higher quality of banking services and products. By comparing the impact of ICT investments on banking performance in SEE region and on global level the research conducted in this study aims to fill in the gap in the existing literature.

\section{Data and methodology}

In order to adequately investigate the effects of digital technologies on business performance in banking industry on global and regional level, two different types of analysis were conducted. Firstly, the impact of investments in ICT on bank's operating expenses was investigated globally and in SEE region. Secondly, the impact of the investments in ICT on the profits of respective regional banks was estimated. For this purpose, the study employed two different panel data sets. The first panel data set consisted of 12 leading banks in SEE region over the period of 2015 and 2019. The choice of banks was based on their regional presence. The following regional banks were analyzed: Addiko bank, Intesa Sanpaolo, Erste Group, Eurobank holding, KBC Group, NLB Group, OTP Group, Pireus Bank SA, Procredit Holding, Sberbank international, Raiffeisen Bank International, Unicredit Bank Group. It is important to highlight that in order to adequately analyze regional performance of the selected banking groups that operates in SEE region, balance positions related to the parent company were isolated from the respective consolidated reports. In some consolidated reports data were already separated by countries, while with others the data were separated by headquarters from the consolidated reports.

The second panel data set consisted of 30 world's leading banks across the globe over the same period. The following global banks were analyzed: Agricultural Bank of China, China Construction Bank Corporation, HSBC, Industrial and Commercial Bank, JP Morgran, Bank of China, BNP Paribas, MUFG Bank, Japan Post Bank, Credit Agricol, Bank of America, Sumitomo mitsui banking corporation, Wells fargo, Banco Santander, Mizuho Bank, Deutsche bank, Société Générale, BPCE, Citibank, Postal Saving Bank of China, Barclays Bank, The Toronto Dominion Bank, Royal bank of Canada, ING bank, The Agricultural Development Bank of China, China merchants bank, UBS AG, Unicredit Group Goldman Sachs, Intesa Saopaolo. 
The data for both panel data sets were obtained from official financial reports of the respective banks, as well as from management presentations intended for external shareholders. With that regard, data on net profit, investments in nontangible assets and operating (non-interest) expenses - OPEX were obtained. Furthermore, data on net profit and investments in nontangible assets were obtained directly from the reports, while OPEX was generated by calculating all non-interest expenses (administrative expenses, salaries etc.).

As a preliminary analysis, the summary statistics for the variables within first panel of banks are presented in Table 1.

Table 1: Panel summary descriptive statistics for regional banks

\begin{tabular}{|l|c|c|c|}
\hline & $\begin{array}{c}\text { Operating expenses of } \\
\text { Banks (opex) (mio Euro) }\end{array}$ & $\begin{array}{c}\text { Profits of Banks } \\
\text { (netprofit) (mio Euro) }\end{array}$ & $\begin{array}{c}\text { Investment in smart information } \\
\text { and communication technologies } \\
\text { (AINVESTNINTAS) (mio Euro) }\end{array}$ \\
\hline Mean & 2961.826 & 887.5983 & 150.5783 \\
\hline Median & 998.8000 & 574.0000 & 69.00000 \\
\hline Std. Dev. & 3563.748 & 2327.250 & 177.5569 \\
\hline Skewness & 1.361477 & -2.119937 & 1.456380 \\
\hline Kurtosis & 3.622619 & 16.75624 & 4.139498 \\
\hline Jarque-Bera & 19.50534 & 509.3928 & 24.45656 \\
\hline Probability & 0.000058 & 0.000000 & 0.000005 \\
\hline
\end{tabular}

Source: authors' calculation

Summary statistics presented in Table 1 indicate that all series are leptokurtic and they do not have normal distributions provided by Jarque-Bera test results. Also, there is high volatility in banks' operating expenses comparing to their profits and investment in smart information and communication technologies as indicated by standard deviation. Moreover, profits of banks seem to be more volatile than the investments. Banks in sample differ in several factors: market share, internal structure, customer base etc. Taking into account the importance of digital technologies in modern society, the low volatility of investments in ICT in sample is expected. On the other hand, net profits are highly determined by main characteristics of client base - both retail and corporate, which is the main factor to explain their high volatility.

The summary statistics for global banks are presented in Table 2.

Table 2. Panel summary descriptive statistics for global banks

\begin{tabular}{|c|c|c|}
\hline & OPEXEUR & INTASSETEUR \\
\hline Mean & 23312.60 & 8351.40 \\
\hline Median & 20272.07 & 3027.50 \\
\hline Std. Dev. & 13640.18 & 13498.05 \\
\hline Skewness & 1.18 & 2.45 \\
\hline Kurtosis & 3.64 & 8.77 \\
\hline Jarque-Bera & 37.23 & 358.40 \\
\hline Probability & 0.0000 & 0.0000 \\
\hline
\end{tabular}

Source: authors' calculation 
Results presented in Table 3 clearly indicate that both series are leptokurtic and that they do not have normal distributions (Jarque-Bera test). Also, there is high volatility in banks' intangible assets, indicated by standard deviation. Position of intangible assets per banks showed some volatility which is in line with intensity of investment activity per banks. Some banks are more intensive and have higher intangible assets' size, other are within investment processes and value of digital investment is not fully presented (booked) among intangible assets position (it is booking gradually). Also, different accounting standards may also impact the aforementioned volatility.

Figure 1 displays the scattergram between period averages of the logarithmic values of banks' operating expenses (log opex) and their investments in smart information and communication technologies (log AINVESTNINTAS) - regionally and globally.

Figure 1: The scattergram between period averages of the logarithmic values of banks' operating expenses (log opex) and their investments in ICT (log ainvestnintas)

10

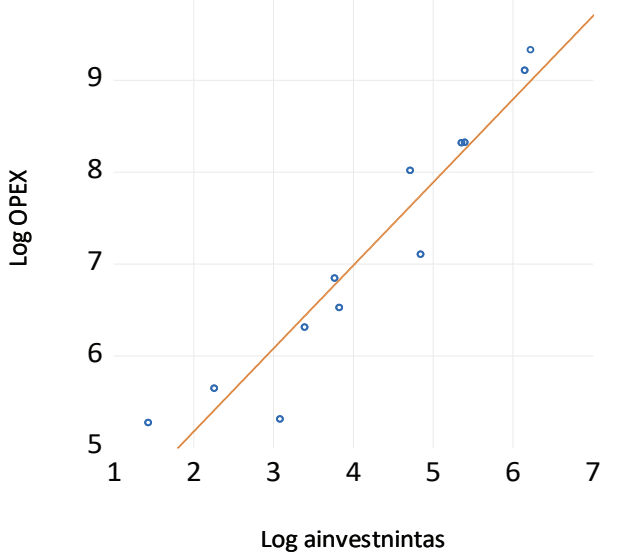

a) Regional banks
13

12

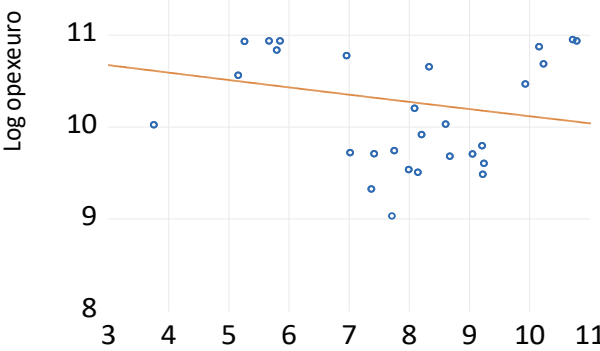

Log aintaseur

b) Global banks

Source: authors' calculation

On average, there is a positive relationship between two variables in first subsample. The scattergram displays significant differences in terms of the relationship between two variables for the respective regional banks (a). For example, two Italian banks Intesa Sanpaolo (Italy) (2) and Unicredit Bank Group (Italy) (12) have the largest amount of investments and operating expenses as oppose to lowest amounts of Procredit Holding (Germany) (9) and NLB Group (Slovenia) (6). Addiko bank's (Austria) (1) operating expenses are relatively low comparing to its investments. Eurobank holding's (Greece) (4) variables exhibit almost positive perfect correlation. Pireus Bank SA (Greece) (8), Sberbank international (Austria) (10) and OTP Group (Hungary) (7) banks' amount of both variables are less than that of Erste Group (Austria) (3), KBC Group (Belgium) (5) and Raiffeisen Bank International (Austria) (11).

On average, in the second subsample (scattergram $b$ ) there is a negative relationship between two variables which is expected.

Figure 2 shows the scattergram between period averages of banks' profits 
(anetprofit) and their investments in smart information and communication technologies (ainvestnintas) for regional banks.

Figure 2: The scattergram between period averages of the banks' profits (anteprofit) and their investments in ICT (ainvestnintas)

\section{5,000}

4,000

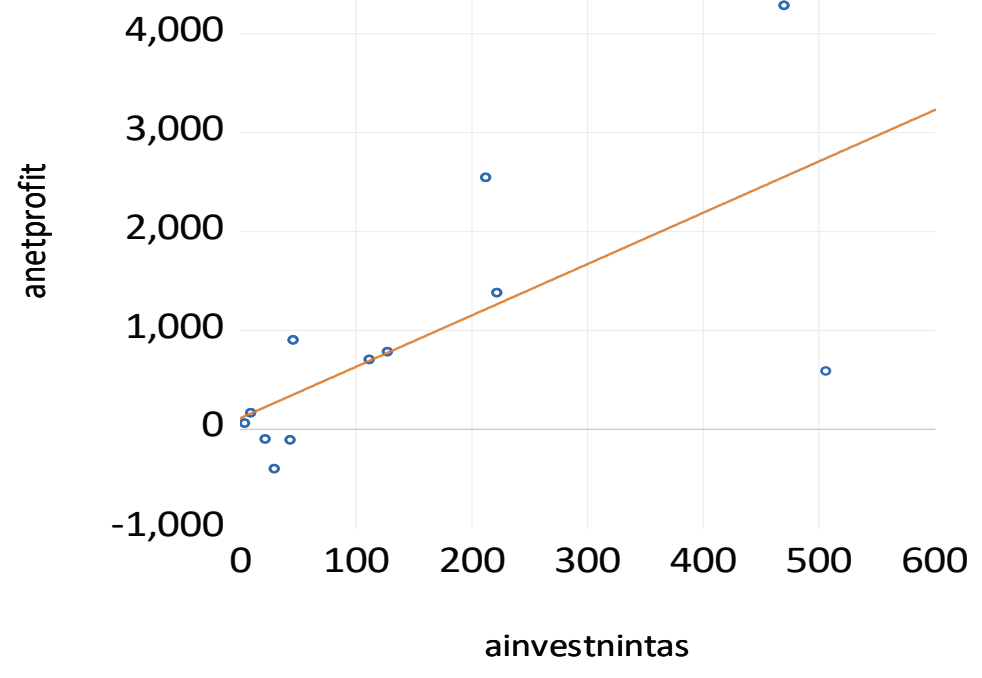

Source: authors' calculation

On average there is a positive relationship between two variables. However, when examined closely, scattergrams show significant differences in terms of the relationships between two variables. For example, Addiko banka (Austria) (1), Eurobank holding (Greece) (4) and Pireus Bank SA (Greece) (8) suffers from loses over the period on average. Sberbank international (Austria) (10) invests relatively small amount money in smart information and communication technologies, but makes high profits. Although amount of investments of Erste Group (Austria) (3) and KBC Group (Belgium) (5), the latter makes more profit than the former. Unicredit Bank Group (Italy) (12) makes highest investment, but earns relatively less profit. Moreover, Intesa Sanpaolo (Italy) (2) makes almost close amount money to investment with Unicredit Bank Group (Italy) (12), but earns highest profit. Procredit Holding (Germany) (9) and NLB Group (Slovenia) (6) invest relatively small amount of money, but still earns profit. Scatter points of OTP Group (Hungary) (7) and Raiffeisen Bank International (Austria) (11) are on the line, representing perfect example if implied positive relationship between two variables.

Following the suggestion of group of authors (Samargandi et al., 2015), we use the static panel data models of fixed effects models to obtain the cross-sectional effects. In addition, to estimate the effects of banks' intangible assets on operating expenses, it is reasonable to assume that the estimator has common slopes and variance, but bank 
specific effects. To estimate this relationship, Fixed Effect Model (FEM) was used. The model employed in this paper is presented in Eq. (1):

$$
y_{\text {it }}=\alpha_{i}+\beta x_{i t}+u_{i t}
$$

where the dependent variables $y_{i}$ are the operating expenses of banks (OPEX) in the first estimation and net profits of regional banks in the second (anteprofit) and independent variable in both exercises $\mathrm{x}_{\mathrm{i}}$ is the investments of banks in smart information and communication technologies. Notice in Eq. (1) that an $i$ subscript is added to only intercept $\alpha_{i}$ but the slope coefficient $(\beta)$ is same for all cross-sectional units. Including an individual constant term, it is aimed to control for individual-specific and time-invariant characteristics, because FEM assumes time-invariant individual-specific effects. That intercepts are called fixed effects. Fixed effects capture the individual heterogeneity, which refers to unobservable bank-specific factors that are time-invariant. Also, as it is mentioned in Tebaldi et al. (2018), the presence of heterogeneity causes regression coefficients to be biased and inconsistent.

To select the most appropriate model in both estimates, two sets of tests are carried out. With the help of first group of tests, it has been decided whether to use the model of Common Effect (CE) or Fixed Effect. For this purpose, three sets of tests were used for testing the significance of cross-section and period fixed effects. In the first set of tests, by using Cross-section F and Cross-section Chi-square (Chow-test), the significance of cross-section fixed effects is tested. In the second sets of tests, it is tested whether or not period fixed effects are significant by using Period F and Period Chi-square tests. Finally, we test joint significance of cross-section and period fixed effects by using the CrossSection/Period F and Cross-Section/Period Chi-square tests.

\section{Results and discussion}

Before estimating the relationship between banks' operating expenses (Log opex) and their investments in smart information and communication technologies (log ainvestnintas) for the regional banks, the above tests were carried out to determine the appropriate model. The Chow-test results (computed value of test statistic 182.668989 and its p-value 0.0000) show that the FEM can be used to estimate the stated relationship above. The results only indicate significant cross-section fixed effect not the period effects. Moreover, Hausman test was used to check whether Random Effects Model (REM) is as good as FEM. Since computed value of Hausman test statistic (Chi-square: 67.699133 and its associated p-value is 0.0000 ) is greater than table Chi-square value (also p-value of test statistic is less than $5 \%$ percent level of significance, it was decided to use FEM instead of REM. Besides the formal test results, to estimate the effect of the investment in smart information and communication technologies on the operating expenses of the banking sector, it is logical to assume that the model has common slopes and variance, but bank specific effects. The same tests were also carried out for global banks. Again the results of the Chow-test results (computed value of test statistic 188.195902 and its associated p-value 0.0000) indicate that the cross-section fixed effects are significant; but the period effects are not leading to the conclusion that the FEM is appropriate to estimate the same relationship between variables for the global banks as well. These results are also verified by Hausman test. 
However, the same tests were carried out to determine the appropriate model to estimate the relationship between banks' profits (anetprofit) and their investments in smart information and communication technologies (ainvestnintas). Chow tests' results indicate significant cross-section fixed effects, but not the period fixed effects. Since computed value of Hausman test statistic (Chi-square: 5.448218 and its associated $\mathrm{p}$-value is 0.0196 ) is greater than table Chi-square value (also p-value of test statistic is less than 5\% percent level of significance, we decide to use FEM instead of REM). Besides the formal test results, to estimate the effect of growth of investment in smart information and communication technologies on the growth of profitability of the banking sector, it is logical to assume that the model has common slopes and variance, but bank specific effects.

In Table 3, the results of FEM for both global and regional banks are presented.

Table 3: The results of panel data models for global and regional banks

\begin{tabular}{|l|c|c|}
\hline & $\begin{array}{c}\text { Cross-section fixed model for } \\
\text { regional banks }\end{array}$ & $\begin{array}{c}\text { Cross-section fixed model for } \\
\text { global banks }\end{array}$ \\
\hline Variables & & $10.41^{*}$ \\
\hline Constant & $6.897^{*}$ & $-0.072^{*}$ \\
\hline LINTASSETEUR & $0.065^{*}$ & ${ }^{*}$ \\
\hline \multicolumn{2}{|c|}{${ }^{*}$ indicates that coefficients are statistically significant at 1 -percent significance level. } \\
\hline
\end{tabular}

Source: authors' calculation

According to FEM results for regional banks, there is a positive relationship between two variables. The results indicate that 1 per cent increase in amount of investments of banks in smart information and communication technologies will lead to approximately 0.065 per cent increase in banks' operating expenses on average. On the other hand, unlike the regional banks, there is an inverse relationship between two variables. Estimated value of the elasticity of OPEX with respect to intangible assets indicate that one-percent increase in intangible assets of banks in sample, on average, will lead to approximately 0.072 percent decrease in operating expenses of banks. This is the consequence of the fact that regional banks in the sample do not develop "in-house" ICT, but rather use parent bank software instead. Other explanation refers to outsourcing of certain modules of core banking information systems, which increases the OPEX (not investments) - in the balance sheets it is not recorded as intangible assets, but as an expense. This is related to existing trend that CAPEX is transformed in OPEX. Unlike regional banks, global banks mainly develop "in-house" ICT by investing billions of dollars or euros which is followed by lesser extent of the outsourcing of certain segments of the information system. Within the largest global banks billions of data are collected in information silos, which are later analyzed with artificial intelligence in order to adequately personalize the customers' needs and to make multi-channels platforms.

Table 4 presents the bank specific cross-sectional effects for regional banks. 
Table 4: Cross-section effects for the regional banks

\begin{tabular}{|l|c|}
\hline \multicolumn{1}{|c|}{ Banks (Cross-section ID) } & Cross-section effects \\
\hline Addiko banka (Austria) (1) & -1.790816 \\
\hline Intesa Sanpaolo (Italy) (2) & 1.809654 \\
\hline Erste Group (Austria) (3) & 1.073538 \\
\hline Eurobank holding (Greece) (4) & -0.299051 \\
\hline KBC Group (Belgium) (5) & 1.072505 \\
\hline NLB Group (Slovenia) (6) & -1.399407 \\
\hline OTP Group (Hungary) (7) & -0.120816 \\
\hline Pireus Bank SA (Greece) (8) & -0.824989 \\
\hline Procredit Holding (Germany) (9) & -1.728986 \\
\hline Sberbank international (Austria) (10) & -0.633744 \\
\hline Raiffeisen Bank International (Austria) (11) & 0.814424 \\
\hline Unicredit Bank Group (Italy) (12) & 2.027688 \\
\hline
\end{tabular}

Source: authors' calculation

The negative values of cross-section effects for certain banks in SEE region are mainly due to layoffs, reduction of the number of branches and sub-branches, and not an increase in efficiency which is a consequence of higher investments in ICT. For example, in the case of Addiko bank (1) the negative cross section effect in the observed period is probably the consequence of change in organizational structure and management aimed at a general reduction of costs caused by the loss of competitive position in the regional market. NLB Group (6) also records negative cross section effect mostly due to radical haircuts and cost reduction strategies in order to clean balance sheet.

Table 5 presents the bank specific cross-sectional effects for global banks.

Table 5: Cross-section effects for global banks

\begin{tabular}{|l|c|}
\hline \multicolumn{1}{|c|}{ Banks (Cross-section ID) } & Cross-section effects \\
\hline Agricultural Bank of China (1) & 0.218837 \\
\hline China Construction Bank (2) & 0.047288 \\
\hline HSBC (3) & 0.736646 \\
\hline Industrial and commercial Bank of China (4) & 0.123650 \\
\hline JP Morgan (5) & 1.249412 \\
\hline Bank of China Limited (6) & 0.112214 \\
\hline BNP Paribas (7) & 0.384347 \\
\hline MUFG Bank (8) & 0.071499 \\
\hline Japan Post Bank (9) & -0.894198 \\
\hline Credit Agricole (10) & -0.188204 \\
\hline Bank of America National Association (11) & 1.182219 \\
\hline Sumitomo Mitsui Banking Corporation (12) & -0.641644 \\
\hline Wells Fargo Bank National Association (13) & 1.192583 \\
\hline Banco Santander SA (14) & 0.991192 \\
\hline Mizuho Bank Ltd (15) & -2.092997 \\
\hline
\end{tabular}




\begin{tabular}{|l|c|}
\hline Deutsche Bank AG (16) & -0.172544 \\
\hline Société Générale (17) & -0.105195 \\
\hline BPCE (18) & -0.182821 \\
\hline Citibank NA (19) & 0.794445 \\
\hline Postal Savings Bank of China Co Ltd (20) & -0.288727 \\
\hline Barclays Bank PLCn (21) & -0.142466 \\
\hline The Toronto-Dominion Bank (22) & -0.304350 \\
\hline Royal Bank of Canada (23) & 0.050169 \\
\hline ING Bank NV (24) & -0.564873 \\
\hline The Agricultural Development Bank of China (25) & 0.188064 \\
\hline China Merchants Bank Co Ltd (26) & -0.818595 \\
\hline UBS AG (27) & 0.212972 \\
\hline UniCredit (28) & -0.347139 \\
\hline Goldman Sachs (29) & 0.081990 \\
\hline Intesa Sanpaolo (30) & -0.893772 \\
\hline
\end{tabular}

Source: authors' calculation

Cross-section effects presented in Table 5 show that vast majority of respective banks in our sub-sample record an inverse relationship between investment in information and communication technologies and OPEX. The vast majority of significantly negative cross section effects are recorded in Japanese banks. This is the consequence of huge investments in sophisticated technological solutions in all of the three banking segments (back office, middle office and front office) which lead us to conclusion that investments in ICT have positive impact on efficiency of all the banking operations.

The conclusions reached in this study implicate the tendency of smaller banks to follow the strategy of the largest ones - to base their core operations on digital processes and platforms. Practically, digitalization process is a matter of necessity. It impacts cost decrease (as has been showed in our study) which leaves room for banks to increase their competitiveness by lowering their offering rates. On the other hand, digital solutions improve time efficiency in providing banking services which is in high demand on the market. The results also suggest the potential for market concentration in banking industry in years to come. Digitalization is followed by large investments in ICT (CAPEX) which usually takes several years to give full result on profitability. Taking into consideration that smaller banks do not have capacity to invest large amount of money and wait for long run return, the mergers and acquisitions in banking industry are expected.

After exploring the regional and global effects of banks' investments in smart information and communication technologies on operating expenses, the impact of these investments on net profit of respective banks in SEE region is evaluated. Based on all relevant tests, after concluding that the usage of FEM is appropriate to estimate the relationship between profitability of the banking sector and investments in smart information and communication technologies, the Eq. (1) is estimated by using OLS.

Table 6 represents the results of FEM by using 12 banks data over the period of 2015-2019. 
Table 6: The results of FEM

\begin{tabular}{|l|c|}
\hline \multicolumn{1}{|c|}{ Variables } & Cross-section fixed model \\
\hline Constant & -1618.11 \\
\hline INVESTNINTAS & 16.61 \\
\hline \multicolumn{2}{|c|}{ indicates that coefficients are statistically significant at 1-percent } \\
significance level.
\end{tabular}

Source: authors' calculation

As it is indicated in scattergram, the results imply positive and statistically significant relationship between investments in smart information and communication technologies (INVESTNINTAS) and banks' profitability (NETPROFIT).

Table 7 displays bank-specific effects.

Table 7: Cross-section effects

\begin{tabular}{|l|c|}
\hline \multicolumn{1}{|c|}{ Banks (Cross-section ID) } & Cross-section effects \\
\hline Addiko banka (Austria) (1) & 1150.058 \\
\hline Intesa Sanpaolo (Italy) (2) & -1919.357 \\
\hline Erste Group (Austria) (3) & -1064.003 \\
\hline Eurobank holding (Greece) (4) & 785.0559 \\
\hline KBC Group (Belgium) (5) & 623.5931 \\
\hline NLB Group (Slovenia) (6) & 1619.660 \\
\hline OTP Group (Hungary) (7) & 275.0074 \\
\hline Pireus Bank SA (Greece) (8) & 717.9462 \\
\hline Procredit Holding (Germany) (9) & 1603.751 \\
\hline Sberbank international (Austria) (10) & 1752.271 \\
\hline Raiffeisen Bank International (Austria) (11) & 456.1183 \\
\hline Unicredit Bank Group (Italy) (12) & -6212.902 \\
\hline
\end{tabular}

Source: authors' calculation

In this case, the cross-section effects basically indicate individual profitability of banks that could be related to the cross-bank variations in unobserved time-invariant factors, or to be more precise to factors which did not considerably/at all change in relatively time span comprised by the sample, such as quality of management, ownership structure etc. Difference between cross-section effects for two banks in this case can be interpreted as a difference in profitability due to time-invariant factors that are observed at the same level of investment in non-tangible assets. For example, if Addiko bank (1) and Intesa Sanpaolo (2) are compared, estimated cross-section effects indicate that at given $\mathrm{X}$ level of investment in non-tangible assets, Addiko bank makes on average 1,150.1-(-1,919.4)=3,069.5 mil EUR higher net profit than Intesa Sanpaolo as the result of better utilization of time-invariant bank-specific factors.

As it can be observed from the results presented in Table 8, investments in ICT recorded growth in almost all banks in the sample, which had the positive impact on the overall banking profitability. However, it can also be noted that certain banks recorded a negative cross-sectional effect which may be a consequence of the time required to optimize new investments. Accordingly, in the forthcoming period the positive effects of ICT investments on the profitability of these banks are expected. 


\section{Concluding remarks}

The results indicate that the influence of investments in ICT on OPEX defers on global and regional level. On average, there is positive relationship between investments in digital and smart technologies and operating costs of banks within sub-sample of regional banks. This is the consequence of the fact that regional banks mostly do not develop „,in-house“ ICT, but rather use parent bank software instead. Other explanation refers to outsourcing of certain modules of core banking information systems, which increases the OPEX (not investments) - in the balance sheets it is not recorded as intangible assets, but as an expense. Unlike regional banks, global banks mainly develop "in-house" ICT by investing billions of dollars or euros which is followed by lesser extent of the outsourcing of certain segments of the information system. Within the largest global banks billions of data are collected in information silos, which are later analyzed with artificial intelligence in order to adequately personalize the customers' needs and to make multi-chanel platforms. Investments in ICT also have impact on the structure of employees: they eliminate the jobs with predominantly manual activities, while in the same time increase the number of employees in the IT sector. In the end, the results of the research conducted also indicate statistically significant positive relationship between investments in ICT and banks' profitability in SEE region.

The conclusions reached in this study imply the tendency of smaller banks to follow the strategy of the largest ones - to base their core operations on digital processes and platforms. Practically, digitalization process is a matter of necessity. It results in reducing costs (as has been showed in our study) which leaves room for banks to increase their competitiveness by lowering their offering rates. On the other hand, digital solutions improve time efficiency in providing banking services which is highly required on the market. The results also suggest the potential for market concentration in banking industry in the future. Digitalization is followed by large investments in ICT (CAPEX) which usually takes several years to give full result on profitability. Taking into consideration that smaller banks do not have capacity to invest large amount of money and wait for long run return, the mergers and acquisitions in banking industry are expected.

Digitization in banking is more than a change based on technology. Moreover, the existing knowledge has to be upgraded and adopted without being lost. The whole new technology process has strong impact on the business, relation with customers, market and regulation. Technical part, data models, reports, and interfaces should be adjusted to enable better decision making, better performance measuring and customers' behavior tracking. Banks should be focused on new digital possibilities such as cloud computing, big to smart data models, business intelligence etc.

The change from manual processes, which may be time and money consuming, to automatic processes which may help banks to better understand customers'needs, cost drivers, and causes of risk is going to mark years to come. However, overall banking market is going to operate between digital and physical. Several factors should keep this balance as follows:

- Strategies should be focused on customers' satisfaction rates, with convenience becoming primary concern. The easier way to achieve customer satisfaction is by providing ability to open any type of account through a mobile device rather than a branch visit (or both). 
- Traditional compensation and targets may be the hugest obstacles banks are confronted with when planning digital strategy. New focus should be followed by new targets which are going to be set to employees. No in-branch products' sales should be in targets.

- Change in demographic also affects digitalization era (especially visible in influence of millennials).

In the end, due to data restrictions (especially their availability) the study fails to use some alternative dynamic panel models. Thus, as we manage to acces the more data on the banks in the sample, the future study will be developed by using dynamic panel metods especially considering the cross-sectional dependence and slope homogeneity.

\section{References}

Belk, R. W. (2013). Extended Self in a Digital World. Journal of Consumer Research, 40 (3), 477-500.

Bouncken, R. B., Kraus, S. \& Roig-Tierno, N. (2019). Knowledge- and innovationbased business models for future growth: digitalized business models and portfolio considerations. Review of Managerial Science, doi: 10.1007/s11846-01900366-z.

Delgosha, M. S., Saheb, T. \& Hajiheydari, N. (2020). Modelling the Asymmetrical Relationships between Digitalization and Sustainable Competitiveness: A CrossCountry Configurational Analysis, Retrieved from: https://doi.org/10.1007/ s10796-020-10029-0. Accessed: 26 July 2020.

Ernst \& Yung (2020). Banking in the New Decade: Three Big Bets to Boost Profitability and Free up Capital to Invest in Transformation, Retrieved form: https://www. ey.com/en_gl/banking-new-decade. Accessed: 26 July 2020.

Ernst \& Yung (2020). Global FinTech Adoption Index 2019: As FinTech becomes the Norm, You need to stand out from the Crowd, Retrieved from; https:// fintechauscensus.ey.com/2019/Documents/ey-global-fintech-adoptionindex-2019.pdf, Accessed: 26 July 2020.

Gerlach, J. M. (2020). Digitization Tendencies in the Traditional Financial Services Industry - Evidence on Changes, Consequences and Implications for the Traditional German Banking Sector [Doctoral Dissertation]. Heinrich Hein University Dieseldorf

Gomber, P., Koch, J.-A. \& Siering, M. (2017). Digital Finance and FinTech: Current Research and Future Research Directions. Journal of Business Economics, 87 (5), 537-580.

Gunter, B. (2016). The Psychology of Consumer Profiling in a Digital Age. New York: Routledge.

Hinson, R \& Sorensen, O. J. (2006). E Business and Small Ghanaian Exporters: Preliminary Micro Firm Exploration in the Light of Digital Divide. Online Informatin Review, 30 (2), 116 -138. 
Hinton, J. (2020). Could Digital Transformation Break the Banking Industry?. Global Banking \& Finance Review. https://www.globalbankingandfinance.com/coulddigital-transformation-break-the-banking-industry/. Accessed: 26 July 2020.

Hoffman, D. L., Novak, T.P. \& Stein, R. (2013). The Digital Consumer. In: Belk, R.W. \& Llamas, R. (Eds.), The Routledge companion to digital consumption (pp. 28-38), New York: Routledge.

Kim, Y., Park, Y.J., Choi, J. \& Yeon, J. (2016). The Adoption of Mobile Payment Services for "FinTech". Internatonal Journal of Applied Engeenering Research, 11(2), 10581061

Kioko, S. (2014). Strategic Responses Adopted by Kenya Commercial Bank Ltd to Digitize Customers Service and Operations in Nairobi Country [A research project submitted in partial fulfillment of the requirement for the award of the degree of Master of business administration], School of Business, University of Nairobi.

Lilley, A. \& Rogoff, K. (2020). Negative Interest Rate Policy in the Post COVID-19 World, Retrieved from: https://voxeu.org/article/negative-interest-rate-policypost-covid-19-world, Accessed: 26 July 2020.

Lončar, D., Đorđević, A., Lazić, M., Milošević, S. \& Ćojbašić Rajić, V. (2016). Interplay Between Market Concentration and Competitive Dynamics in the Banking Sector: Evidence from Serbia, Croatia, Romania and the Czech Republic. Journal of Business Economics and Management, 64 (5-6), 332-346.

Mekinjić, B. (2019). The Impact of Industry 4.0 on the Transformation of the Banking Sector. Journal of Contemporary Economics, 6-28.

Nadella, S., Shaw, G. \& Nichols, J.T. (2017). Hit Refresh: The Quest to Rediscover Microsoft's Soul and Imagine a Better Future for Everyone. New York: Harper Collins Publisher.

Nylund, P.A., Ferras-Hernandez, X. \& Brem, A. (2018). Automating Profitably Together: Is There an Impact of Open Innovation and Automation on Firm Turnover?. Review of Managerial Science, 14, 269-285.

Philippon, T. (2016). The Fintech Opportunity (NBER Working Paper), Cambridge, MA: National Bureau of Economic Research.

Pousttchi, K., Moormann, J. \& Felten, J. (2015). The Impact of New Media on Bank Processes: A Delphi Study. International Journal of Electronic Business, 12 (1), DOI: 10.1504/IJEB.2015.068305.

Price Waterhouse Cooper (2011). The New Digital Tipping Point, Retrieved from: https://www.pwc.com/gx/en/banking-capital-markets/publications/assets/ pdf/pwc-new-digital-tipping-point.pdf, Accessed: 26 July 2020.

Prokopović. K. S., Prokopović, T. B. \& Jelić M. A. (2016). Information Technologies in Integrated Logistics. Ekonomika, 62, 175-186.

Rodrigues, J. F. C., Ferreira, F. A. F., Pereira, L. F., Carayannis, E. G. \& Ferreira, J. J. M. (2020). Banking Digitalization: (Re)Thinking Strategies and Trends using Problem Structuring Methods. IEEE Transactions on Engineering Management, $1-15$. 
Samargandi, N., Fidrmuc, J. \& Ghosh, S. (2015). Is the Relationship between Financial Development and Economic Growth Monotonic? Evidence from a Sample of Middle-Incom Countries. World Development, 68, 66-81.

Schullo, J. R. \& Zimerman, S. (2000). Electronic Marketing: Integrating Electronic Resources into Marketing Process. Orlando: Harcourt College Publishers.

Serebrennikova, A. I., Kuvayeva, Y. V. \& Chilimova, T. A. (2019). Innovations in Banks: Areas and Challenges. In: The International Scientific and Practical Forum Industry. Science. Competence. Integration (pp 177-184), ISCI 2019: Industry Competitiveness: Digitalization, Management, and Integration.

Sheth, J. N. \& Solomon, M. R. (2014). Extending the Extended Self in a Digital World. Journal of Marketing Theory and Practice, 22 (2), 123-132.

Swacha-Lech, M. (2017). The Main Challenges Facing the Retail Banking Industry in the Era of Digitalization. Journal of Insurance, Financial Markets and Consumer Protection, 26 (4/2017), 94-116.

Tebaldi. E., Nguyen, H. \& Zuluaga, J. (2018). Determinants of Emerging Markets' Financial Health: A Panel Data Study of Sovereign Bond Spreads. Research in International Business and Finance, 45, 82-93.

Yip, A. W. H. \& Bockenab, N. M. P. (2018). Sustainable Business Model Archetypes for the Banking Industry. Journal of Cleaner Production, 174, 150-169.

Valvedere, S. C. \& Fernandez, F. R. (2020). Financial Digitalization: Banks, FinTech, BigTech, and Consumers, Journal of Financial Management and Market Institutions, 8 (01), 1-13. 